\title{
RANCANG BANGUN SISTEM INFORMASI PENJUALAN MEUBEL (STUDI KASUS: CV. FAJAR INDAH AMUNTAI)
}

\author{
Windarsyah $^{1)}$, Muhammad Alkaff ${ }^{2)}$ \\ ${ }^{1,2)}$ Universitas Lambung Mangkurat, \\ e-mail: windarsyah@unlam.ac.id ${ }^{1)}, \underline{\text { m.alkaff@unlam.ac.id }}{ }^{2)}$
}

\begin{abstract}
ABSTRAK
Salah satu media informasi yang banyak digunakan oleh beberapa perusahaan sekarang ini adalah sistem informasi berbasis desktop dimana suatu aplikasi diharapkan dapat membantu mempermudah dalam menyelesaikan suatu masalah. Meubel Fajar Indah Amuntai dalam mengelola data barang, harga dan laporan hasil transaksi masih menggunakan media kertas atau buku tulis dalam menyimpan data-data tersebut, namun ketika ada perubahan harga barang maka data tersebut ditulis kembali di buku yang baru, sehingga waktu dan biaya terbuang untuk menulis dan membeli buku baru. Untuk mengidentifikasi kebutuhan sistem dalam penelitian ini menggunakan metode analisis berarah aliran data. Dari analisis yang dilakukan diperoleh informasi masukan, keluaran dan proses sistem yang diharapkan, yaitu berupa fasilitas untuk memanipulasi data operator, memanipulasi data barang, mencatat setiap transaksi penjualan, dapat menampilkan dan mencetak laporan. Dengan hasil analisis dapat diperoleh rancangan antar muka yang lebih user friendly dan easy to use.
\end{abstract}

Kata kunci: system informasi, user friendly, easy to use.

\begin{abstract}
One of the media information that is widely used by some companies today is desktop-based information systems where an application is expected to help facilitate in resolving a problem. Furniture Fajar Indah Amuntai in managing goods data, pricing and reporting the results of the transaction is still using paper media or notebook in storing such data, however, when there are changes in prices of goods then the data is written back in a new book, so the time and cost of wasted writing and buying new books. To identify the needs of the system in this study using data flow trending analysis. From the information obtained by the analysis conducted inputs, outputs and system processes that are expected, which is a facility operator to manipulate data, manipulate data items, records every sales transaction, it can display and print the report. With the analysis results can be obtained interface design is more user friendly and easy to use.
\end{abstract}

Keywords: information system, user friendly, easy to use.

\section{PENDAHULUAN}

Perkembangan dunia teknologi informasi berkembang begitu pesat, salah satunya berbasis aplikasi. Aplikasi Desktop merupakan perkembangan dari teknologi informasi yang memiliki kemampuan untuk digunakan oleh lebih dari satu pengguna dalam satu kali waktu atau bisa disebut dengan Multi User (banyak pengguna), sehingga aplikasi desktop banyak dibutuhkan oleh masyarakat terutama dibidang perusahaan, dimana suatu aplikasi diharapkan dapat membantu dan mempermudah dalam menyelesaikan suatu masalah. Sebelum perusahaan memiliki aplikasi yang dibutuhkan, perusahaan tersebut hanya memasukkan data-datanya kedalam sebuah buku daftar harga barang, buku transaksi penjualan barang, dan lain sebagainya. Pada daftar harga barang contohnya, sewaktu-waktu harga barang bisa berubah, maka perusahaan akan menuliskan kembali harga-harga baru per bulan bahkan per minggu. Sehingga perusahaan membuang banyak waktu dan biaya untuk membeli buku baru, bahkan apabila terjadi suatu bencana yang tidak diinginkan dapat saja menghilangkan data tersebut.

Berdasarkan hal diatas itulah yang menjadi alasan untuk membahas lebih lanjut mengenai penggunaan Apliksasi Desktop sebagai media untuk mengatasi masalah-masalah tersebut diatas, yang nantinya diharapkan sistem informasi berbasis Aplikasi Desktop ini dapat mempermudah dan membantu dengan lebih efektif dan efisien dalam memperbaharui data-data pada perusahaan Meubel Fajar Indah Amuntai.

\section{LANDASAN TEORI}

\section{A. Meubel Fajar Indah}

Meubel Fajar Indah mulai beroperasi pada tahun 1987 yang didirikan oleh Bpk. H. Khairullah yang beralamat di Jl. Jarang Kuantan. No. 107. Amuntai. Jenis barang meubel yang pertama kali dibuat adalah kursi kantor, Seiring berjalannya waktu, beliau mempunyai keinginan untuk menambah variasi model, antara lain, Kursi tamu, Rak TV, Meja makan, Kursi makan dan lain-lain. Pemasaran hasil produksi awalnya hanya di daerah Kalimantan Selatan saja hingga saat ini telah memasuki pasar antar pulau, terutama pulau Sulawesi. Agar dapat tetap bersaing dengan perusahaan meubel yang lain, Meubel Fajar Indah Amuntai selalu berinovasi membuat model baru, sehingga para pelanggan tidak jenuh dengan barang yang itu-itu saja hingga sekarang 


\section{B. Visual Basic 6}

Visual Basic adalah salah satu bahasa pemrograman komputer. Bahasa pemrograman adalah perintah yang dimengerti oleh komputer untuk melakukan tugas-tugas tertentu. Bahasa pemrograman Visual Basic, yang dikembangkan oleh Microsoft sejak tahun 1991, merupakan pengembangan dari pendahulunya yaitu bahasa pemrograman BASIC (Beginner's All-purpose Symbolic Instruction Code) yang dikembangkan pada era 1950-an. Visual Basic merupakan salah satu Development Tool yaitu alat bantu untuk membuat berbagai macam program komputer, khususnya yang menggunakan sistem operasi Windows. Visual Basic merupakan salah satu bahasa pemrograman komputer yang mendukung object Object Oriented Programming (OOP). [1]

Aplikasi adalah suatu unit perangkat lunak yang dibuat untuk melayani kebutuhan akan beberapa aktivitas. Aplikasi akan menggunakan sistem operasi (OS) komputer dan aplikasi lainnya yang mendukung Apl. Istilah ini mulai perlahan masuk kedalam istilah Teknologi Informasi semenjak tahun 1993. Secara historis, aplikasi adalah software yang dikembangkan oleh sebuah perusahaan sebelumnya. [2]

C. SQL Server

Microsoft SQL Server adalah suatu produk andalan Microsoft untuk database server. Kemampuan dalam manajemen data dan kemudahan pengoperasian membuat Database Management System (DBMS) menjadi pilihan para database administrator. SQL Server adalah sebuah mesin database client/server yang berbeda dengan database komputer tunggal tradisional yang memakai sistem pemakaian file secara bersama-sama (misalnya Dbase, Microsoft Jet, Microsoft Visual FoxPro). Database sistem memakai file secara bersama-sama bergantung pada sebuah proses tunggal per user untuk memanipulasi data pada file yang dipakai bersama pada server jaringan. Bagi pengembang database, SQL Server kompatibel dengan beberapa data access interface yang digunakan dalam Development Tool seperti pada Visual Basic, Visual C++, Power Builder, Delphi, Visual FoxPro dan sebagainya. Database SQL Server dapat diakses dengan menggunakan Microsoft Jet Engine dan Data Access Object (DAO), Remote Data Object (RDO), ActiveX Data Object (ADO), OLEDB, ODBC, SQL Server built-in Library dan interface dari third party lainnya. SQL Server memberikan bahasa dan antarmuka (interface) yang baik untuk pemrograman dan komunikasi pada server. Transact-SQL merupakan bahasa pemrograman server yang merupakan superset dari ANSI-SQL yang mendefinisikan empat perintah dasar untuk manipulasi data yaitu : SELECT, INSERT, UPDATE, DELETE dan sejumlah perintah untuk mendefinisikan struktur database. Transact-SQL menambahkan beberapa hal pada ANSI-SQL. Penambahan tersebut adalah konstruksi pemrograman yang memungkinkan pemakaian stored procedure untuk mengubah data dan trigger yang akan dijalankan karena terjadi event tertentu. [3]

\section{METODE PENELITIAN}

\section{A. Analisis Kebutuhan}

Metode sangat diperlukan dalam membuat analisis terhadap pembuatan dan pengembangan suatu sistem. Metode analisis berfungsi untuk menganalisis kebutuhan perangkat lunak dalam membangun Sistem Informasi pada perusahaan Meubel Fajar Indah Amuntai. Metode analisis yang digunakan dalam perancangan sistem ini adalah metode berarah aliran data, yaitu dengan cara mengumpulkan data yang dibutuhkan dengan metode observasi atau langsung datang ke lokasi serta membuat sistem yang diinginkan.

B. Kebutuhan Perangkat Lunak

Untuk mengetahui bebutuhan perangkat lunak, diperlukan analisis yang mempunyai tahapan sebagai berikut :

1) Masukan Data Sistem

Masukan data sistem diperoleh dari keterangan pemilik perusahaan berupa keterangan data operator, data barang, harga penjualan dan laporan transaksi penjualan

2) Analisis Kebutuhan Fungsi

Dalam Sistem Informasi ini, sistem akan digunakan oleh pemilik perusahaan yang mana terdapat beberapa proses, yaitu :

- $\quad$ Proses Otorisasi

Dalam penggunaan sistem ini harus terlebih dahulu melakukan login untuk masuk kedalam sistem

- $\quad$ Proses Input

Pada proses input, sistem memerlukan data operator yang terdiri atas kode operator, nama operator, jenis kelamin, alamat, username dan password. Data barang yang terdiri Kode barang, nama barang harga satuan dan jumlah stok

- Proses Edit Basis Data

Proses edit ini digunakan untuk mengubah dan memperbaharui data lama yang telah tersimpan dalam database menjadi data baru. Basis data yang termasuk dalam proses edit yaitu basis data operator, barang, stok, harga satuan, penjualan

- Proses Hapus Basis Data

Proses ini dimaksudkan untuk menghapus data yang tidak digunakan atau diperlukan lagi. Basis data yang termasuk dalam proses hapus yaitu basis data operator, barang, stok, harga satuan, penjualan

- Proses Update Barang Otomatis

Update barang otomatis yaitu merubah jumlah stok barang pada basis data barang ketika perusahaan melakukan penjualan. Jika perusahaan melakukan penjualan maka secara otomatis jumlah stok barang dalam basis data barang akan berkurang

- $\quad$ Proses Cari dan Tampil Barang

Proses ini digunakan untuk memudahkan pengguna dalam mencari data serta dapat digunakan untuk menampilkan data yang dibutuhkan dengan cepat. Basis data yang termasuk dalam proses pencarian adalah pencarian data barang berdasarkan jenis dan berdasarkan nama barang

3) Keluaran Data Sistem 
Keluaran atau output dari sistem informasi Aplikasi Penjualan Barang Meubel Fajar Indah Amuntai ini adalah data yang telah diproses menjadi suatu infomasi yang diinginkan oleh pengguna.

Data keluaran yang dihasilkan oleh sistem ini adalah :

- Informasi mengenai nama,harga dan stok barang.

- Informasi pencarian barang berdasar jenis dan nama barang.

- Informasi transaksi penjualan barang.

- Informasi laporan hasil per transaksi, per periode dan seluruh penjualan.

\section{Metode Perancangan Sistem}

Pada proses sistem informasi Aplikasi Penjualan ini dimulai dari pembuatan database dengan menggunakan MySQL, dilanjutkan dengan pembuatan form dan penulisan program dengan menggunakan Visual Basic 6.0 untuk mengambil dan menampilkan informasi-informasi yang diinginkan.

1) Data Flow Diagram (DFD)

Pada tahap perancangan, diagram yang menggunakan notasi untuk menggambarkan arus data sistem adalah diagram arus data Data Flow Diagram (DFD). Pada DFD level 1, Sistem Infomasi Aplikasi Meubel Fajar Indah Amuntai ini terdiri dari 6 proses :

- Proses login, proses ini digunakan untuk masuk kedalam sistem.

- Proses manajemen operator, proses ini untuk memasukkan, mengubah atau menghapus operator yang telah tersimpan dalam database.

- Proses olah data, proses ini untuk memasukkan, mengubah atau mengahapus data barang yang telah tersimpan dalam database.

- $\quad$ Proses pencarian barang, proses ini digunakan untuk mencari barang yang diinginkan dengan memasukkan jenis barang atau nama barang.

- Proses transaksi, proses ini digunakan untuk mencatat semua hasil transaksi penjualan barang kepada pelanggan.

- Laporan, proses ini untuk menerangkan secara global sistem transaksi barang dan dan data stok dan harga satuan barang yang ada digudang.

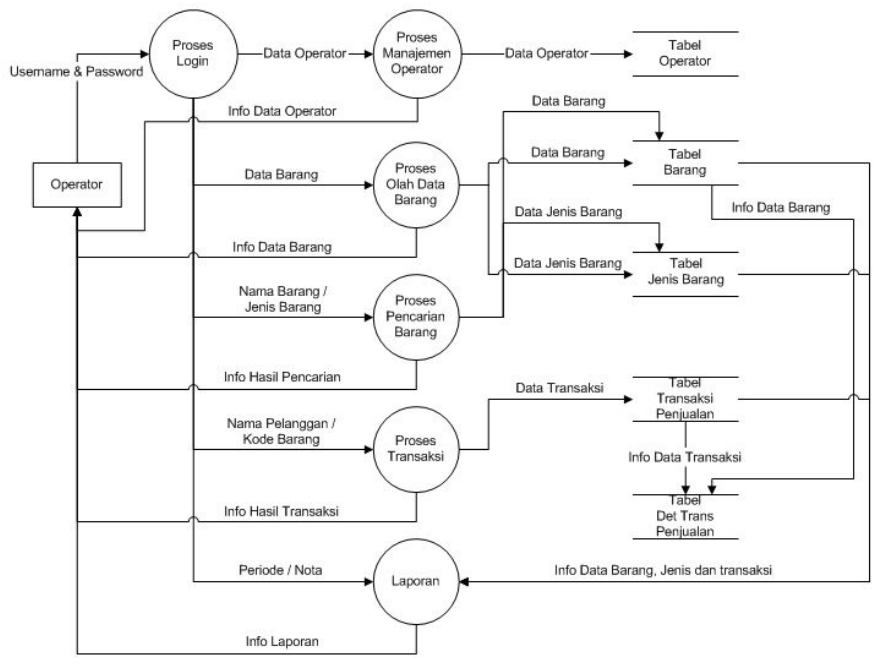

Gambar 1. DFD level 1

2) Relasi Antar Tabel

Dalam pemodelan struktur data, hubungan antar data pada sistem informasi menggunakan diagram relasi antar tabel yang mana dengan adanya diagram relasi antar tabel ini akan menunjukkan hubungan antar tabel yang satu dengan yang lainnya. 


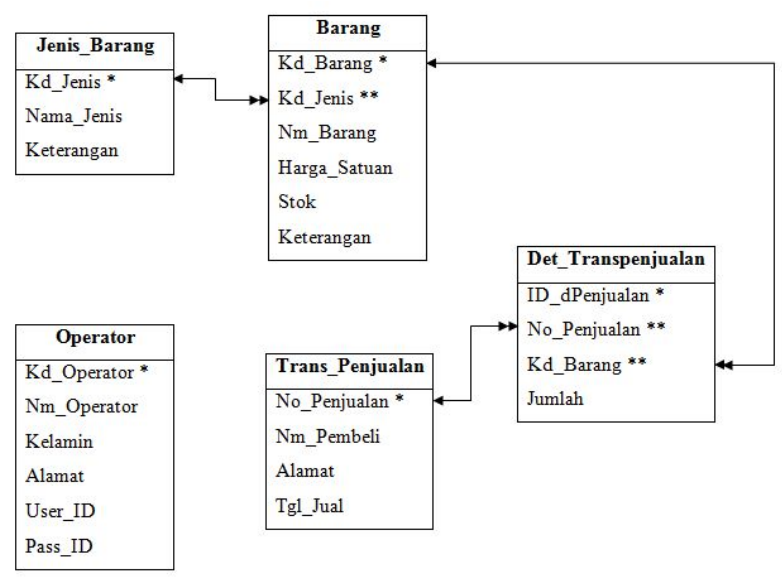

\section{HASIL DAN PEMBAHASAN}

\section{A. Implementasi Program}

Implementasi program merupakan hasil dari analisis dan desain sistem yang telah dilakukan sebelumnya. Berikut ini adalah sub-sub bab yang menjelaskan implementasi dari analisis dan desain sistem.

\section{1) Form Login}

Pada saat membuka Aplikasi Penjualan ini, tampilan pertama yang muncul adalah Form Login. Sebelum masuk form utama, Operator atau pengguna diharuskan untuk Login dengan mengisikan Username dan Password. Hal ini dilakukan sebagai langkah pengamanan sistem. Tombol 'Login' untuk masuk ke aplikasi dan tombol 'Keluar' digunakan utnuk keluar dari sistem. Tampilan seperti pada gambar.4.1.

\section{2) Form Utama}

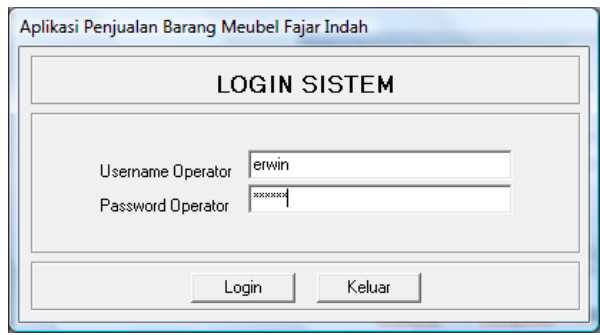

Gambar 3. Tampilan Form Login

Pada form utama terdapat beberapa menu yaitu, pada Tab Administrasi terdapat Login \& Logout Sistem, Manajemen Operator dan Keluar Sistem, pada Tab Barang terdapat Data jenis Barang dan Data Barang, pada Tab Pencarian terdapat Pencarian Data Barang, pada Tab Transaksi terdapat Transaksi Penjualan, pada Tab Laporan terdapat Seluruh Data Jenis Barang, Data Barang Per Jenis, Data Stok Barang, Seluruh Transaksi Penjualan, Transaksi Penjualan Per Nota dan Transaksi Penjualan Per Periode. Adapun gambar form utama seperti pada Gambar.4.2

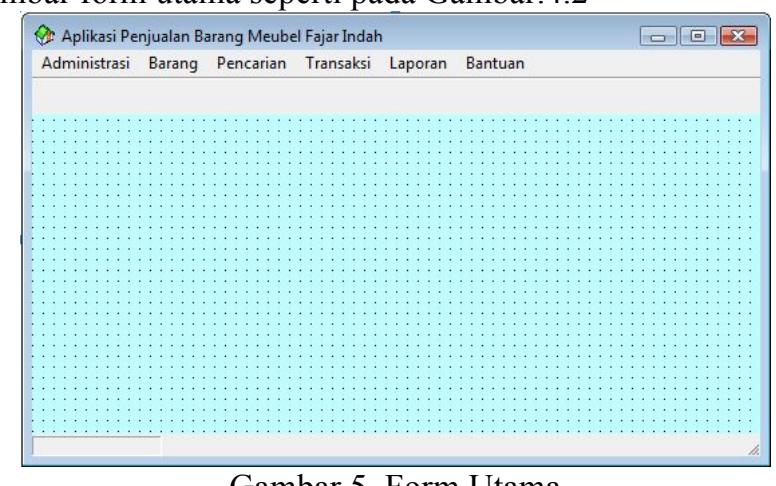

\section{3) Form Manajemen Operator}

Gambar 5. Form Utama

Pada tampilan ini operator dapat melakukan proses input, edit dan hapus data operator. Apabila operator ingin menambahkan operator baru, terlebih dahulu mengklik 'Tambah', pada Kode Jenis muncul secara otomatis saat mengklik 'Tambah', apabila data tersebut belum terisi lengkap, maka data baru tersebut tidak dapat disimpan hingga data yang diminta terisi semua, barulah dapat diklik 'Simpan' atau klik 'Batal' untuk menghapus semua data yang telah diisi sebelum disimpan. Kemudian untuk merubah atau mengedit data yang sudah ada, operator dapat memilih 'Ubah' lalu memlilih kode operator yang akan dirubah atau klik 'Batal' untuk menghapus semua data yang telah diisi sebelum diupdate, barulah operator boleh mengklik 'Update' atau mengklik 'Hapus' jika ingin menghapus operator yang kode operatornya sudah dipilih sebelumnya. Dan klik 'Keluar' jika ingin menyudahi pengolahan data operator. 


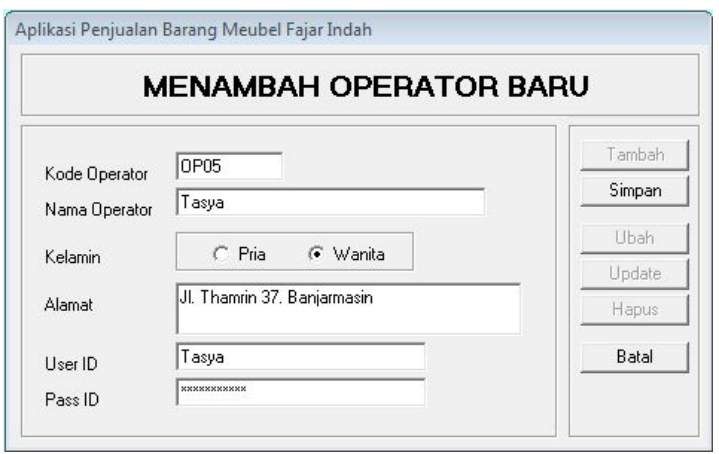

4) Form Data Jenis Barang

Gambar 6. Form Manajemen Operator

Pada tampilan ini operator dapat membuat jenis baru, mengubah dan menghapus jenis dari pengelompokan barang-barang yang ada. Operator harus mengklik 'Tambah' terlebih dahulu, baru dapat memasukkan data seperti Nama Jenis dan Keterangannya, pada Kode Jenis muncul secara otomatis saat mengklik 'Tambah', apabila sudah terisi keduanya, barulah dapat mengklik 'Simpan' atau klik 'Batal' untuk menghapus semua data yang telah diisi sebelum disimpan. Jika ingin mengubah data jenis yang telah ada, operator dapat mengklik 'Ubah' dan memilih Kode Jenis yang ingin diubah, jika sudah dirubah barulah operator boleh mengklik 'Update' atau klik 'Batal' untuk menghapus semua data yang telah diisi sebelum diupdate atau mengklik 'Hapus' jika ingin menghapus Jenis yang Kode Jenisnya sudah dipilih sebelumnya. Dan klik 'Keluar' jika ingin menyudahi pengolahan data Jenis.

\section{5) Form Data Barang}

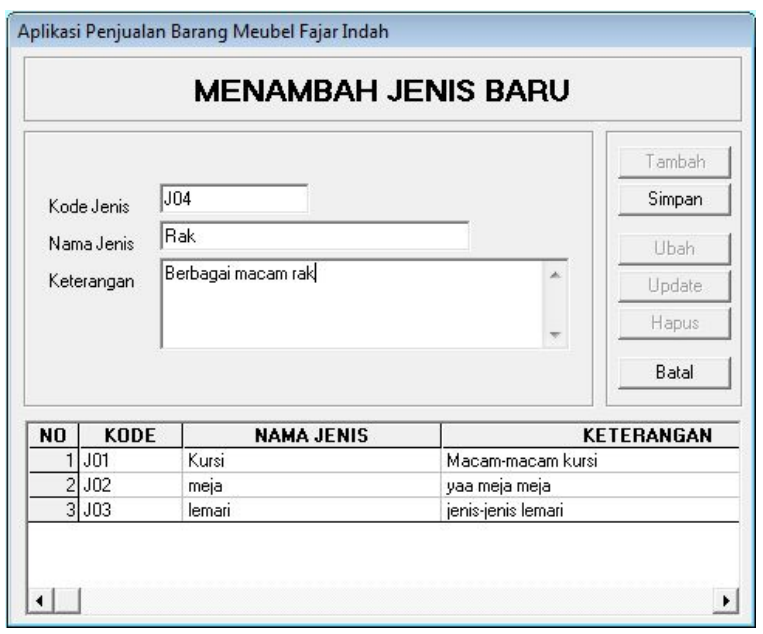

Gambar 7. Form Data Jenis Barang

Pada tampilan ini operator dapat membuat data barang baru, mengubah dan menghapus barang. Operator harus mengklik 'Tambah' terlebih dahulu, baru dapat memasukkan data seperti Nama Barang, Harga, Stok, kode Jenis dan Keterangannya, pada Kode Barang muncul secara otomatis saat mengklik 'Tambah', apabila sudah terisi semua, barulah dapat mengklik 'Simpan' atau klik 'Batal' untuk menghapus semua data yang telah diisi sebelum disimpan. Jika ingin mengubah data barang yang telah ada, operator dapat mengklik 'Ubah' dan memilih Kode Barang yang ingin diubah, jika sudah dirubah barulah operator boleh mengklik 'Update' atau klik 'Batal' untuk menghapus semua data yang telah diisi sebelum diupdate atau mengklik 'Hapus' jika ingin menghapus Barang yang Kode Barang sudah dipilih sebelumnya. Dan klik 'Keluar' jika ingin menyudahi pengolahan data Barang. 


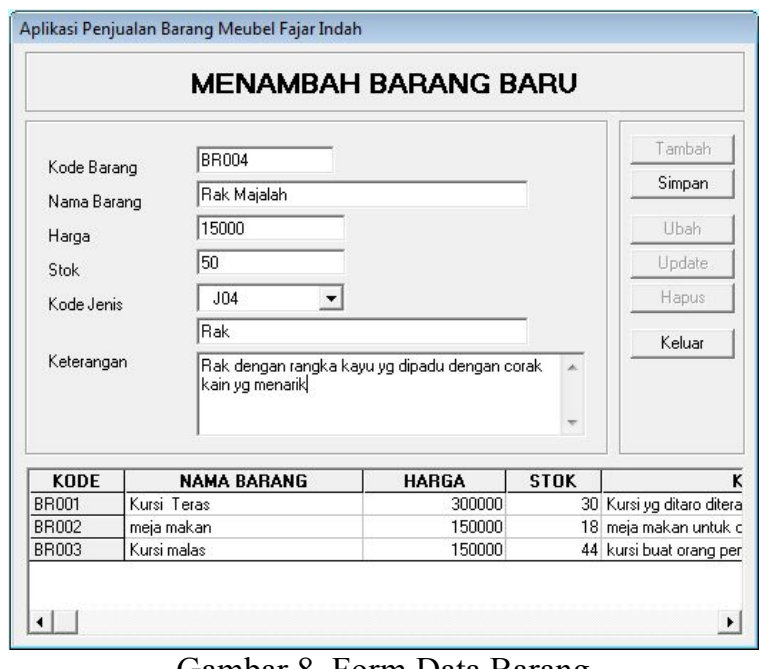

6) Form Pencarian Data Barang

Gambar 8. Form Data Barang

Pada tampilan ini operator dapat mencari data barang berdasarkan jenis dan nama. Operator dapat mencari barang berdasarkan jenis dengan memilih jenis yang sudah ada pada database dan dapat pula mencari dengan memasukkan nama barang yang ingin dicari. Klik 'Semua' untuk menampilkan semua data barang dan 'Keluar' untuk keluar dari tampilan Informasi dan pencarian barang.

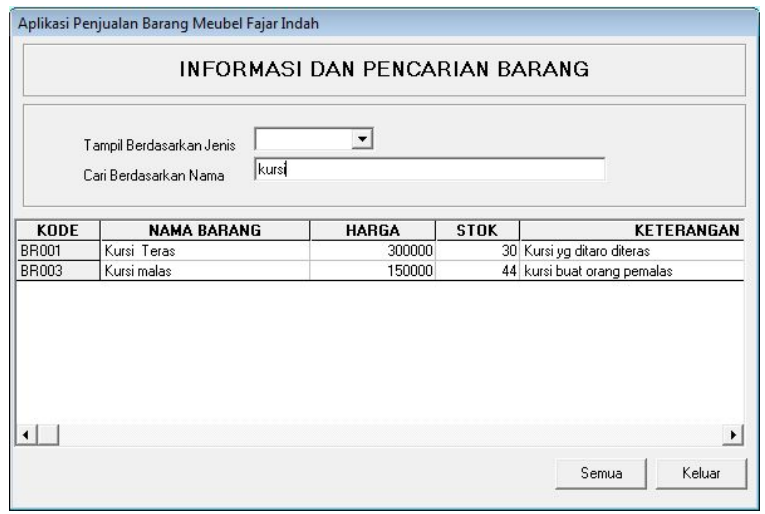

Gambar 9. Form Pencarian Data Barang

7) Form Transaksi Penjualan Barang

Ditampilan ini operator dapat memasukkan data transaksi. Pertama-tama operator mengklik 'Baru' umtuk melakukan penginputan data transaksi, kemudian "No Penjualan" dan "Tgl Penjualan" akan terisi secara otomatis, lalu operator memasukkan nama "Pelanggan" dan "Alamat" pelanggan, setelah itu operator memlilih barang yang akan dibeli pelanggan di kolom "Daftar Barang" dan memasukkan jumlah barang yang akan dibeli oleh pelanggan dan klik "OK", maka barang yang dipilih tersebut akan masuk ke tabel penjualan dan inputan ini dapat diulangi lagi sesuai daftar barang yang dibeli oleh pelanggan. Jika sudah selesai, dibawah tabel penjualan terdapat "Total Bayar" yaitu jumlah harga yang harus dibayar oleh pelanggan, kemudian operator memasukkan jumlah uang yang dikasih oleh pelanggan, apabila uang yang dikasih pelanggan berlebih, maka akan keluar jumlah uang kembaliannya, setelah itu klik "Simpan" untuk selesai atau "Batal" untuk menghapus data transaksi penjualan sebelum disimpan dan "Keluar" untuk menyudahi penginputan data transaksi.

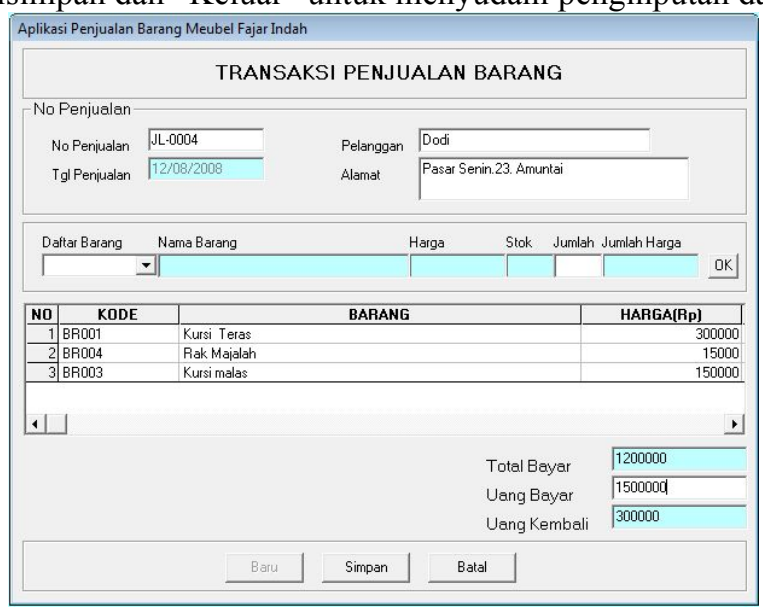

Gambar 10. Form Penjualan Barang 
8) Form Laporan Semua Jenis

Pada Tab laporan, pilihan yang pertama yaitu 'Seluruh Data Jenis Barang' yang isinya adalah daftar nama jenis barang yang terdapat di database. Disini terdapat fitur 'Print' (gambar printer) untuk mencetak laporan daftar jenis barang dan "Export" (gambar buku) untuk menyimpan laporan keformat .html dan .txt, ada juga pilihan 'Zoom' untuk memperbesar atau memperkecil tampilan. Untuk keluar dari tampilan laporan, operator dapat mengklik tanda " $\mathrm{x}$ ” dipojok kanan atas tampilan.

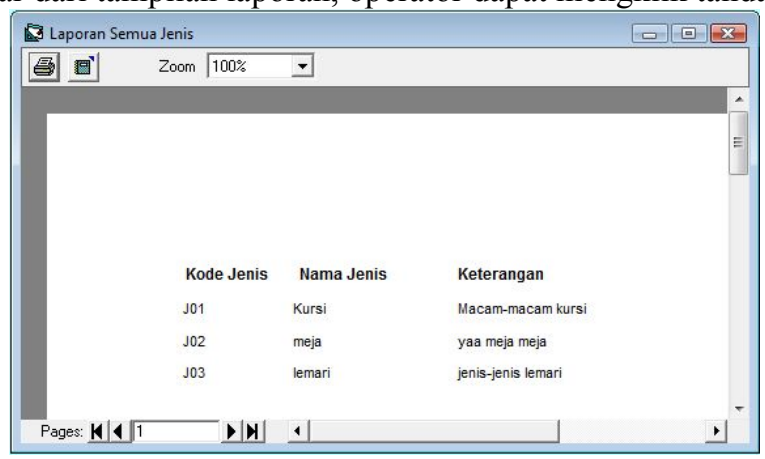

Gambar 11. Laporan Semua Jenis

9) Form Laporan Barang Per Jenis

Pilihan yang kedua yaitu 'Data Barang Per Jenis' yang isinya adalah daftar nama barang yang terdapat dalam pengelompokan jenis. Sebelumnya operator diminta memasukkan 'Kode Jenis' terlebih dahulu, barulah dapat mengklik "Tampil" untuk menampilkan laporan atau "Keluar" untuk menutup tampilan. Disini terdapat fitur yang sama dengan tampilan form laporan diatas.

10) Form Laporan Stok Barang

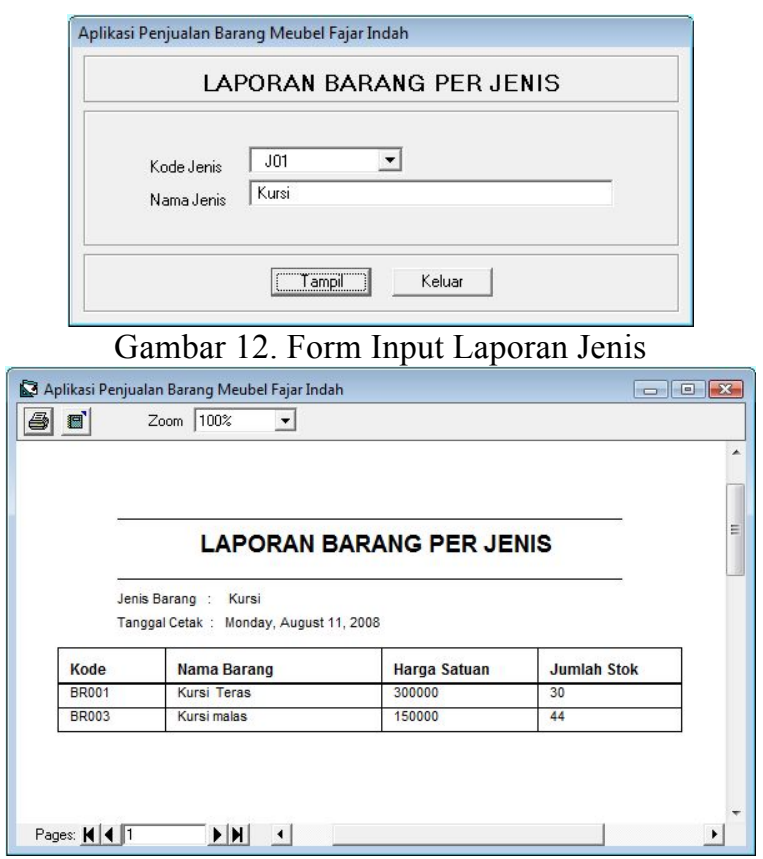

Gambar 13. Laporan Barang Per Jenis

Pilihan yang ketiga yaitu 'Data Stok Barang' yang isinya adalah daftar semua barang yang terdapat dalam database. Disini terdapat fitur yang sama dengan form laporan diatas.

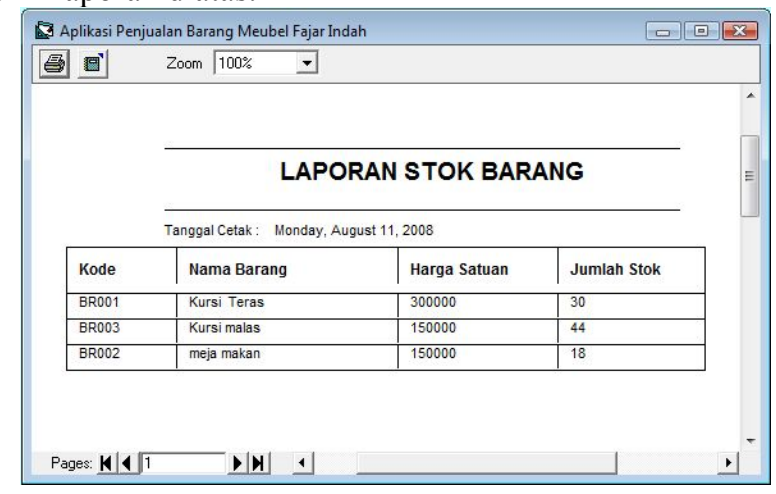

Gambar 14. Laporan Stok Barang 
11) Form Laporan Transaksi Penjualan

Pilihan yang keempat yaitu 'Semua Transaksi Penjualan' yang isinya adalah daftar semua transaksi yang telah tersimpan dalam database. Disini terdapat fitur yang sama dengan form laporan diatas

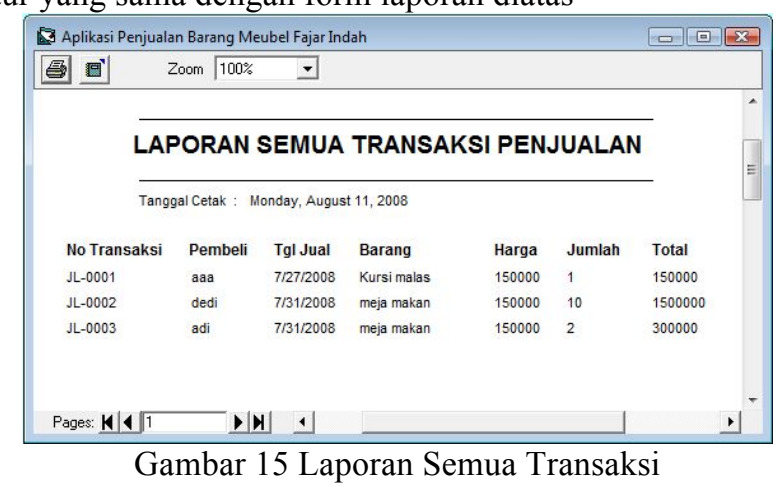

12) Laporan Penjualan Per Transaksi

Pilihan yang kelima yaitu 'Transaksi Penjualan Per Transaksi' yang isinya adalah daftar barang yang telah dibeli oleh seorang pelanggan. Sebelumnya operator diminta memasukkan 'No Penjualan' terlebih dahulu, barulah dapat mengklik "Tampil" untuk menampilkan laporan atau "Keluar" untuk menutup tampilan. Disini terdapat fitur yang sama dengan diatas
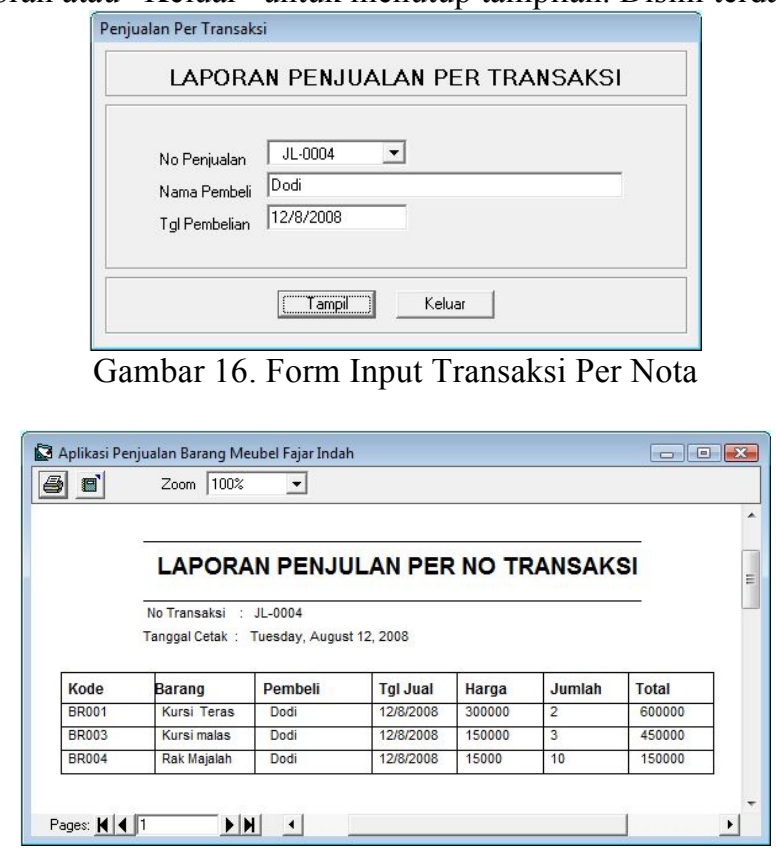

Gambar 17. Laporan Per Transaksi

\section{PENUTUP}

\section{A. Kesimpulan}

Aplikasi Sistem Informasi ini berfokus pada penjualan barang pada Meubel Fajar Indah Amuntai, selain difokuskan pada input data barang dan juga merupakan sistem informasi yang menangani seluruh kelengkapan pengolahan data transaksi penjualan. Oleh sebab itu, dapat disimpulkan bahwa :

- Mempermudah perusahaan Meubel Fajar Indah Amuntai untuk menyimpan data dalam jumlah yang banyak dengan lebih mudah dan efisien.

- Mempermudah perusahaan Meubel Fajar Indah Amuntai untuk mengolah data manajemen seperti menambah, menyimpan, mengubah atau menghapus data operator, data barang, dan data transaksi penjualan dengan lebih mudah.

- Merupakan langkah awal bagi perusahaan Meubel Fajar Indah Amuntai untuk mulai memanfaatkan teknologi informasi.

Sistem informasi ini dibangun hanya dapat digunakan untuk satu bagian tertentu saja. Tetapi informasi yang ada pada sistem informasi ini mungkin akan sangat berguna bagi bagian-bagian lain.

Meskipun sistem informasi ini dibangun sedemikian rupa untuk menangani masalah pendataan, tetapi sistem informasi ini masih memiliki kekurangan seperti masalah perhitungan manajemen perusahaan yang lebih kompleks.

B. Saran 
Sistem informasi Meubel Fajar Indah Amuntai masih sangat sederhana. Sistem ini masih dapat dikembangkan secara kompleks dengan beberapa fasilitas dan dapat menangani masalah yang lebih rumit. Salah satu pengembangan sistem yang dapat dilakukan diantaranya:

- Menambahkan perhitungan laba/rugi perusahaan setiap hari, setiap bulan dan setiap tahun.

- Adanya sistem backup data setiap periode ataupun waktu yang dinginkan secara otomatis, sehingga meminimalisasi kemungkinan hilangnya data secara menyeluruh

\section{DAFTAR PUSTAKA}

[1].Nugroho, Bunafit. Membuat Aplikasi Penjualan dengan Visual Basic 6.0 dan MySQL. Yogyakarta: Penerbit Ardana Media, 2007.

[2].MADCOMS. Aplikasi Data Base \& Cristal Report pada Visual Basic 60, Penerbit ANDI, Yogyakarta, 2004

[3].Nugroho,Bunafit. Dasar Membuat Aplikasi Penjualan dengan Visual Basic 6.0 \& MySQL, A tyRDANAMEDIA, Yogyakarta, 2006 